\title{
Analisis Korelasi Perubahan Iklim Terhadap Kualitas Dan Kuantitas Hasil, Perubahan Teknologi Dan Pendapatan Petani Padi Di Kabupaten Manokwari (Studi Kasus Petani Di Distrik Prafi)
}

\author{
Dedy Riantoro ${ }^{1}$, Maria Magdalena Semet ${ }^{2}$ \\ ${ }^{1,2}$ Dosen Jurusan Ekonomi Pembangunan, Universitas Papua
}

Received: Mei 2019; Accepted: Juli 2019; Published: September 2019

\begin{abstract}
Abstrak
Penelitian ini bertujuan untuk menganalisis korelasi perubahan iklim terhadap kualitas dan kuantitas hasil, perubahan teknologi, dan pendapatan petani padi di Kabupaten Manokwari (studi kasus petani di Distrik Prafi). Jenis penelitian ini kuantitatif asosiatif. Jenis data yang digunakan adalah data primer yang diperoleh melalui pendekatan observasi dan wawancara kepada petani padi untuk menjelaskan hubungan perubahan iklim terhadap pendapatan, kualitas padi dan perubahan teknologi yang dilakukan di Distrik Prafi Kabupaten Manokwari. Dan data sekunder yang diperoleh dari Badan Pusat Statistik (BPS) dan Dinas Pertanian dan Ketahanan Pangan Kabupaten Manokwari. Adapun metode pengumpulan data menggunakan metode observasi, wawancara, kuesioner dan metode kepustakaan. Sedangkan metode analisisnya menggunakan analisis crosstabs (tabulasi silang). Dengan uji signifikansi menggunakan chi-square analysis. Hasil penelitian menunjukan tidak terdapat korelasi perubahan iklim terhadap kualitas dan kuantitas hasil, perubahan teknologi, dan pendapatan petani padi di Kabupaten Manokwari.
\end{abstract}

Kata kunci: Perubahan Iklim, Kualitas dan Kuantitas Hasil, Perubahan Teknologi, Pendapatan Petani

\begin{abstract}
This study aims to analyze the correlation of climate change on the quality and quantity of yields, technological change, and rice farmers' income in Manokwari Regency (case study of farmers in Prafi District). This type of research is quantitative associative. The type of data used is primary data obtained through an observation and interview approach to rice farmers to explain the relationship of climate change to income, rice quality and technological changes made in the Prafi District of Manokwari Regency. And secondary data obtained from the Central Statistics Agency (BPS) and the Agriculture and Food Security Agency of Manokwari Regency. The data collection method uses the method of observation, interviews, questionnaires and literature methods. While the analysis method uses crosstabs analysis (cross tabulation). With the significance test using chi-square analysis. The results showed there was no correlation of climate change on the quality and quantity of yields, technological change, and rice farmers' income in Manokwari Regency.
\end{abstract}

Keywords: Climate Change, Quality and Quantityp Product, Technology Change, Farmer Income

How to Cite: Riantoro, D., Semet, M.M. (2019). Analisis Korelasi Perubahan Iklim Terhadap Kualitas Dan Kuantitas Hasil, Perubahan Teknologi, Dan Pendapatan Petani Padi Di Kabupaten Manokwari (Studi Kasus Petani Di Distrik Prafi). JFRES: Journal of Fiscal and Regional Economy Studies, 2 (1), $42-53$.

\footnotetext{
Corresponding author :

E-mail: omded69@gmail.com
} 


\section{PENDAHULUAN}

Pemanasan global merupakan salah satu kondisi yang buruk bagi bumi. Akhir-akhir ini pemanasan global menjadi ancaman yang serius bagi bumi dan juga makhluk hidup yang ada di dalamnya. Karena pemanasan global ini merupakan kondisi yang sangat buruk maka bisa dikatakan sebagai salah satu jenis bencana alam. Pemanasan global ini dapat memunculkan berbagai macam dampak atau akibat. Salah satu dampak yang diakibatkan dari pemanasan global yaitu terjadinya pergantian musim yang tidak teratur. Pemanasan global ini membuat suhu rata-rata di bumi menjadi meningkat. Meningkatnya suhu rata-rata di bumi ini tidak hanya membuat bumi menjadi terasa lebih panas, banyak makhluk hidup yang mati, bahkan juga akan membuat pergantian musim menjadi tidak stabil. Pergantian musim yang tidak stabil ini membuat musim yang ada sebelumnya menjadi sulit diprediksi pergantiannya. Terkadang satu musim lebih lama terjadi dari pada musim yang lainnya. Akibatnya di Indonesia hujan turun di musim-musim yang biasanya berlangsung musim kemarau dan terkadang musim kemarau berlangsung terlalu lama dari pada biasanya. Hal ini akan membawa berbagai macam dampak buruk kepada manusia dan juga makhluk hidup lainnya.

Berdasarkan prediksi dampak perubahan iklim diberbagai kawasan didunia dimuat dalam jurnal ilmiah Nature, dijelaskan bahwa dalam satu dekade dari sekarang diperkirakan kawasankawasan tropis di dunia akan menghadapi dampak perubahan iklim yang parah dan jauh lebih awal dibandingkan kawasan Arktik dan lainnya.Kota yang akan mengalami kondisi perubahan iklim paling awal di dunia adalah Manokwari.

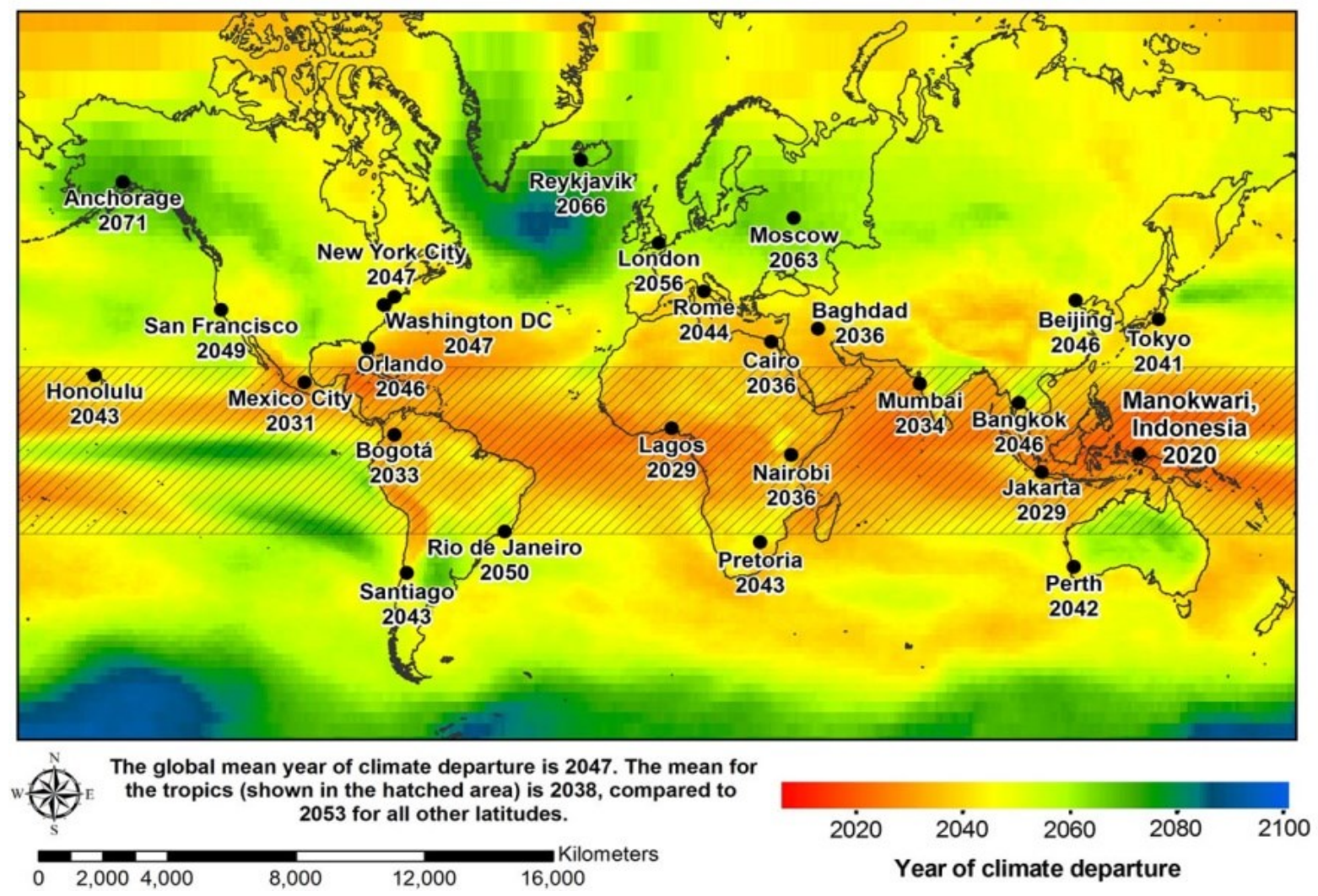

Sumber: Wihardandi, A.(2013)

Gambar 1. Peta Perubahan Iklim

Jakarta, yang diperkirakan akan mencapai suhu paling panas di tahun 2029.Selebihnya, rata-rata berbagai kota di Asia akan mengalami cuaca paling panas di tahun 2040-an. Seperti yang diperkirakan terjadi dengan Beijing, Cina dan Bangkok, Thailand (2046), Tokyo, Jepang (2041), dan Mumbai, India (2034). Dapat dilihat pada Gambar 1. 
Faktor-faktor yang mempengaruhi perubahan iklim yaitu suhu udara, kelembaban udara, curah hujan, cuaca ekstrim seperti banjir dan kekeringan. Menurut data BPS Kabupaten Manokwari jumlah curah hujan dapat dilihat pada tabel 1 .

Tabel 1. Curah Hujan di Kabupaten Manokwari

\begin{tabular}{cc}
\hline Tahun & Curah Hujan $\mathbf{( m m}^{\mathbf{3}} \mathbf{)}$ \\
\hline 2013 & 597,1 \\
\hline 2014 & 282,4 \\
\hline 2015 & 676,0 \\
\hline 2016 & 417,5 \\
\hline 2017 & 576,9
\end{tabular}

Sumber: BPS Kab. Manokwari (2014-2018)

Berdasarkan data pada tabel 1 dapat dijelaskan bahwa jumlah curah hujan tertinggi yaitu pada tahun 2015 sebesar $676,0 \mathrm{~mm}^{3}$ sedangkan jumlah curah hujan terendah yaitu pada tahun 2014 sebesar $282,4 \mathrm{~mm}^{3}$.

Perubahan iklim ternyata memberi dampak juga terhadap sektor pertanian. Sektor pertanian rentan terhadap perubahan iklim karena berpengaruh terhadap pola tanam, waktu tanam, indeks pertanaman, produksi dan kualitas hasil. Data menunjukkan bahwa perubahan iklim berupa pemanasan global dapat menurunkan produksi pertanian antara $5-20 \%$ (Suberjo, 2009). Sebagai contoh, di bagian selatan Indonesia terjadi musim hujan semakin pendek yang berdampak pada sulitnya upaya meningkatkan indeks pertanaman, dan ini harus diatasi dengan menanam varietas yang berumur pendek, atau merehabilitasi jaringan irigasi.

Pada sektor pertanian tentunya tidak terlepas dari peran petani. Hal ini dikarenakan betapa pentingnya peran petani dalam rantai perekonomian sehingga rantai perekonomian itu dapat terus berjalan dengan baik dan lancar. Produktivitas padi di Manokwari, Papua Barat dilakukan oleh para transmigran asal Jawa di daerah transmigrasi Satuan Pemukiman (SP). Dalam membudidayakan padi belum diketahui masalah apa saja yang disebabkan oleh perubahan iklim yang terjadi. Dalam satu tahun pertama hasil panen padi bagus namun untuk tahun berikutnya sudah mengalami penurunan kualitas padi. Dalam masa tanam pertama jumlah produksi padi dapat mencapai 1 hingga 3 ton. Namun dalam masa tanam kedua jumlah produksi mengalami penurunan sebesar kurang dari 1,5 ton hal ini diakibatkan karena adanya serangan hama. Untuk mendapatkan kualitas padi yang baik yaitu dengan menggunakan benih yang berbeda setiap masa tanamnya. Kualitas padi pada masa tanam pertama curah hujan tinggi memberikan hasil yang lebih bagus sedangkan pada masa tanam kedua pada musim kemarau hasilnya kurang baik karena terserang hama.

Disisi lain, menurut data Dinas Pertanian dan Ketahanan Pangan Kabupaten Manokwari perkembangan luas panen, produktivitas dan produksi padi dapat dilihat pada tabel 2 .

Tabel 2. Perkembangan Luas Panen, Produktivitas, dan Produksi Padi

\begin{tabular}{crrr}
\hline Tahun & $\begin{array}{c}\text { Luas Panen } \\
\text { (Ha) }\end{array}$ & $\begin{array}{c}\text { Produktivitas } \\
\text { (Ton/Ha) }\end{array}$ & $\begin{array}{c}\text { Produksi } \\
\text { (Ton GKG) }\end{array}$ \\
\hline 2013 & 4.090 & 3,52 & 14.397 \\
\hline 2014 & 4.120 & 3,55 & 14.626 \\
\hline 2015 & 4.176 & 3,75 & 15.660 \\
\hline 2016 & 4.176 & 3,80 & 15.869 \\
\hline 2017 & 4.476 & 3,85 & 17.223 \\
\hline
\end{tabular}

Sumber: Dinas Pertanian dan Ketahanan Pangan Kab. Manokwari (2018)

Berdasarkan data pada tabel 2 dapat dijelaskan bahwa perkembangan luas panen, produktivitas dan produksi padi mengalami kenaikan secara perlahan setiap tahunnya.

Tabel 3. Data Kelompok Tani Padi Sawah

\begin{tabular}{llr}
\hline Distrik & \multicolumn{1}{c}{ Kampung } & \multicolumn{1}{c}{ Jumlah } \\
\hline Prafi & Prafi Mulya & 310 \\
\cline { 2 - 3 } & Desay & 337 \\
\cline { 2 - 3 } & Sidomuncul Andagau & 89 \\
\cline { 2 - 3 } & Aimasi & 128 \\
\cline { 2 - 3 } & Udapi Hilir & 171 \\
\hline Total & 5 Kampung & $\mathbf{1 . 0 3 5}$ \\
\hline
\end{tabular}

Sumber: Dinas Pertanian dan Ketahanan Pangan Kab. Manokwari (2018)

Adapun jumlah anggota tani per kampung dijelaskan pada tabel 3, dimana terdapat lima kampung di Distrik Prafi dan memiliki jumlah anggota kelompok tani padi sawah sebanyak 1.035 orang.

Dari data-data dan studi kasus yang telah disampaikan diatas dapat dilihat terjadinya 
perkembangan luas panen, tingkat produktivitas, dan produksi padi serta jumlah tenaga kerja petani padi walaupun berfluktuasi. Hal ini menimbulkan tanda tanya apakah terdapat korelasi antara perubahan iklim dan sektor pertanian di Kabupaten Manokwari, sehingga perlu dilakukan penelitian untuk melihat hubungan perubahan iklim terhadap sektor pertanian khususnya pada petani padi dengan rumusan masalah sebagai berikut:

1. Apakah ada hubungan antara perubahan iklim dengan kualitas dan kuantitas hasil serta perubahan teknologi secara bersama-sama?

2. Apakah ada hubungan antara kualitas dan kuantitas hasil dengan pendapatan?

3. Apakah ada hubungan antara perubahan teknologi dengan pendapatan?

Iklim adalah rata-rata jangka panjang dari kondisi atmosfer (cuaca) di suatu tempat. Secara singkat iklim dapat dikatakan sebagai rata-rata dari cuaca. Cuaca suatu daerah akan berfluktuasi dalam rentang waktu detik sampai harian. Nilai rataan dari kondisi unsur-unsur cuaca pada jangka panjang merupakan gambaran dari kondisi iklim daerah tersebut. Kemajuan teknologi informasi, memperkirakan perubahan iklim disebabkan oleh perubahan komposisi atmosfer atau faktor-faktor lainnya, secara umum, relatif dapat dilakukan (Handoko et al. 2008).

Perubahan iklim adalah perubahan variabel iklim, khususnya suhu udara dan curah hujan yang terjadi secara berangsur-angsur dalam jangka waktu yang panjang antara 50 sampai 100 tahun (intercentenial). Perubahan iklim tersebut disebabkan oleh kegiatan manusia (anthropogenic), khususnya yang berkaitan dengan pemakaian bahan bakar fosil dan alihguna lahan. (Aliadi et al.2008). Indikator perubahan iklim merupakan aspek-aspek yang sangat penting terhadap statistik perubahan iklim yang terjadi. Menurut World Climate Change 1979 indikator perubahan iklim adalah sebagai berikut:

1. Suhu Udara; Perubahan suhu udara di satu tempat dengan tempat lainnya bergantung pada ketinggian tempat dan letak astronomisnya (lintang). Perubahan suhu karena perbedaan ketinggian jauh lebih cepat daripada perubahan suhu karena perbedaan letak lintang. Biasanya, perubahan suhu terjadi berkisar 0,6 derajat celcius tiap kenaikan $100 \mathrm{~m}$.

2. Tekanan Udara; Tekanan udara adalah berat massa udara pada suatu wilayah. Tekanan udara menunjukkan tenaga yang bekerja untuk menggerakkan massa udara dalam setiap satuan luas tertentu. Tekanan udara semakin rendah jika semakin tinggi dari permukaan laut.

3. Angin; Angin adalah massa udara yang bergerak dari suatu tempat ke tempat lain. Tiupan angin terjadi jika di suatu daerah terdapat perbedaan tekanan udara, yaitu tekanan udara maksimum dan minimum. Angin bergerak dari daerah bertekanan udara maksimum ke minimum.

4. Kelembaban Udara; Kelembaban udara adalah kandungan uap air dalam udara. Uap air yang ada dalam udara berasal dari hasil penguapan air di permukaan bumi, air tanah, atau air yang berasal dari penguapan tumbuhtumbuhan.

5. Curah Hujan; Hujan adalah peristiwa sampainya air dalam bentuk cair maupun padat yang dicurahkan dari atmosfer ke permukaan bumi.

6. Hasil Produksi; Hasil produksi adalah segala sesuatu yang dihasilkan oleh produsen. Jadi dengan adanya proses produksi yang dilakukan oleh petani padi akan memberikan hasil produksi untuk meningkatkan pendapatan.

Menurut World Bank, 2008 dalamHandoko et al. (2008), adaptasi merupakan suatu proses dimana masyarakat membuat dirinya menjadi lebih baik menghadapi ketidakpastian hasil panen dimasa mendatang. Adaptasi perubahan iklim merupakan suatu upaya yang benar untuk mengurangi dampak negatif dengan melakukan suatu penyesuaian atauperubahan. Beberapa pilihan untuk melakukan adaptasi terhadap perubahan iklim diantaranya peningkatan sistem teknologi seperti meningkatkan keamanan laut 
atau melindungi kawasan pemukiman di sekitar pesisir pantai, merubah pola pikir seseorang untuk melakukan adaptasi terhadap perubahan iklim, mengurangi penggunaan air pada saat terjadi kekeringan, dan menggunakan insektisida pembasmi hama. Upaya perbaikan sistem informasi mengenai kondisiiklim yang terjadi di suatu wilayah perlu dilakukan dalam rangka memperkuat perencanaan dan koordinasi, melakukan investasi pada pengembangan teknologi dan menciptakan sistem keuangan yang efektif dalam upayaantisipasi perubahan iklim.

Menurut Soekartawi (2002), penerimaan adalah hasil kali antara produksi yang diperoleh dengan harga jual. Mubyarto (1994), menyatakan bahwa pendapatan petani merupakan penerimaan yang dikurangi dengan biaya-biaya yang dikeluarkan dalam usahatani dan pemasaran hasil pertanian.

Kualitas padi yang baik yaitu padi dengan bulir yang besar, berwarna putih bersih, dan tingkat kepecahan padi sangat kecil. Quantity (kuantitas) adalah segala bentuk satuan ukuran yang terkait dengan jumlah hasil kerja dan dinyatakan dalam ukuran angka atau yang dapat dipadankan dengan angka. Indikator pada kualitas dan kuantitas hasil padi petani yaitu pemilihan benih, pemeliharaan tanaman, varietas benih padi, dan perubahan teknologi (Wungu dan Brotoharsojo, 2003).

.Nana Syaodih S. (1997: 67) menyatakan bahwa sebenarnya sejak dahulu teknologi sudah ada atau manusia sudah menggunakan teknologi. Kalau manusia pada zaman dulu memecahkan kemiri dengan batu atau memetik buah dengan galah, sesungguhnya mereka sudah menggunakan teknologi, yaitu teknologi sederhana. Terkait dengan teknologi, Anglin mendefinisikan teknologi sebagai penerapan ilmu-ilmu perilaku dan alam serta pengetahuan lain secara bersistem dan menyistem untuk memecahkan masalah. Sedangkan Iskandar Alisyahbana (1980:1) merumuskan lebih jelas dan lengkap tentang definisi teknologi yaitu cara melakukan sesuatu untuk memenuhi kebutuhan manusia dengan bantuan alat dan akal sehingga seakan-akan memperpanjang, memperkuat, atau membuat lebih ampuh anggota tubuh, panca indera, dan otak manusia. Teknologi telah dikenal manusia sejak jutaan tahun yang lalu karena dorongan untuk hidup yang lebih nyaman, lebih makmur dan lebih sejahtera. Jadi sejak awal peradaban sebenarnya telah ada teknologi, meskipun istilah "teknologi belum digunakan.

Hipotesis merupakan jawaban sementara terhadap rumusan masalah penelitian, dimana rumusan masalah penelitian telah dinyatakan dalam bentuk pertanyaan. Hipotesis dikatakan sementara karena jawaban yang diberikan baru didasarkan pada teori (Sugiyono, 2009)

Ho = Diduga perubahan iklim tidak berkorelasi signifikan terhadap pendapatan petani padi, kualitas padi, dan perubahan teknologi.

$\mathrm{H} 1=$ Diduga perubahan iklim berkorelasi signifikan terhadap pendapatan petani padi, kualitas padi, dan perubahan teknologi

\section{METODE PENELITIAN}

Penelitian ini dilaksanakan di Distrik Prafi Kabupaten Manokwari, Provinsi Papua Baratdilaksanakan kurang lebih selama 1 bulan.Jenis penelitian ini adalah penelitian kuantitatif jenis asosiatif. Hal tersebut sesuai dengan pendapat Sugiyono (2009:115). Penelitian ini dilaksanakan dengan menggunakan prosedur penelitian deskriptif inferensial untuk menguji pengaruh variabel bebas terhadap variabel terikat. Variabel bebasnya adalah pendapatan, kualitas dan kuantitas, serta perubahan teknologi. Sedangkan variabel terikat adalah perubahan iklim.

Subjek dalam penelitian ini yaitu petani padi yang mengalami perubahan iklim. Objek dalam penelitian ini yaitu pendapatan, kualitas padi dan perubahan teknologi yang dilakukan oleh petani padi. Data primer diperoleh melalui pendekatan observasi dan wawancara kepada petani padi untuk menjelaskan hubungan perubahan iklim terhadap pendapatan, kualitas padi dan perubahan teknologi yang dilakukan di Distrik Prafi Kabupaten Manokwari. Data sekunder yang dipakai dalam penelitian ini bersumber dari Badan Pusat Statistik (BPS) dan Dinas Pertanian dan Ketahanan Pangan Kabupaten Manokwari. 
Populasi dalam penelitian ini adalah seluruh petani yang ada di Distrik Prafi Kabupaten Manokwari dengan jumlah petani sebanyak 1035 orang. Besarnya jumlah sampel diperoleh dengan menggunakan rumus Slovin tingkat kesalahan toleransi $10 \%$, sehingga diperoleh jumlah sampel sebanyak 91 orang. Pengambilan sampel dalam penelitian ini menggunakan teknik probability sampling berupa simple random sampling.

Metode analisis data yang digunakan dalam penelitian ini adalahSPSS dengan menggunakan metode crosstabs (tabulasi silang). Dengan uji signifikansi menggunakan chi-square analysis. Analisis ini akan dilakukan dengan menyebarkan kuesioner yang bersifat terbuka karena disebarkan kepada petani padi di Distrik Prafi Kabupaten Manokwari.

\section{Pengujian Hipotesis Asosiatif (Hubungan)}

Menguji hipotesis asosiatif menguji hubungan antara dua variabel atau lebih yang ada pada sampel untuk diberlakukan pada seluruh populasi dimana sampel diambil. Untuk mencari hubungan antara dua variabel atau lebih dilakukan dengan menghitung korelasi antara variabel yang akan dicari hubungannya. Korelasi merupakan angka yang menunjukkan arah dan kuatnya hubungan antara dua variabel atau lebih. Arah dinyatakan dalam bentuk hubungan positif dan negatif, sedangkan kuatnya hubungan dinyatakan dalam besarnya koefisien korelasi.

Koefisien korelasi positif $=1$

Koefisien korelasi negatif $=-1$

Koefisien korelasi terkecil $=0$

Terdapat bermacam-macam teknik statistik korelasi yang dapat digunakan untuk menguji hipotesis asosiatif. Teknik korelasi mana yang akan dipakai tergantung pada jenis data yang akan dianalisis. Pengujian penelitian ini menggunakan analisis jenis statistik nonparametris. Jenis statistik nonparametrisyang digunakan untuk menguji hipotesis asosiatif adalah sebagai berikut :

a. Bila datanya berbentuk nominal/diskrit adalah menggunakan Koefisien Kontingensi.

b. Bila datanya ordinal, menggunakan Korelasi Rank Spearman, dan Kendal Tau.

\section{Tabulasi Silang (Crosstabs)}

Analisis tabulasi silang (Crosstabs) adalah metode analisis yang paling sederhana tetapi memiliki daya menerangkan cukup kuat untuk menjelaskan hubungan antar variabel. Untuk itu ada beberapa prinsip sederhana yang perlu diperhatikan dalam menyusun tabel silang agar hubungan antara variabel tampak dengan jelas. Untuk itu maka dalam analisis crosstabs digunakan analisis statistik yaitu Chi Kuadrat (Chi-Square) yang disimbolkan dengan $\chi^{2}$.

\section{Model Analisis Crosstabs danUji Chi-Square}

Metode analisis ini digunakan untuk menguji korelasi antara variabel dalam tabel kontingensi sehingga diketahui apakah proporsi dari dua peubah terjadi karena kebutuhan atau karena adanya asosiasi. Test ini cukup sederhana dan mudahdihitung dari hasil tabel silang. Dalam analisis tabel silang, peneliti menggunakan distribusi frekuensi pada sel-sel dalam tabel sebagai dasar untuk menyimpulkan hubungan antara variabel-variabel penelitian sehingga dengan demikian dapat dengan mudah melihat keterkaitan hubungan antara dua variabel.

Chi-kuadrat merupakan alat statistik yang sangat sederhana yang mana dalam angka itu tidak diketahui apakah hubungannya positif atau negatif, bagaimana hubungan tersebut linier atau non linier dan seberapa erat hubungan antara dua variabel maka digunakan koefisien kontigensi. Naman demikian perlu di tekankan bahwa koefisien kontigensi juga merupakan ukuran statistik sederhana.

Dari penjelasan diatas dapat disimpulkan bahwa analisis crosstabs merupakan suatu metode analisis statistik yang digunakan untuk melihat keterkaitan/hubungan antara dua variabel dengan menggunakan chi-square dan koefisien kontigensi. Atas dasar inilah yang kemudian dinilai bahwa analisis crosstabs dapat menggambarkan keterkaitan hubungan dalam penelitian ini mengenai keterkaitan antara faktor berpengaruh (faktor analisis) dengan faktor terpengaruh (pola pergerakan).

Rumus-rumusnya adalah sebagai berikut: 
a. Nilai Korelasi:

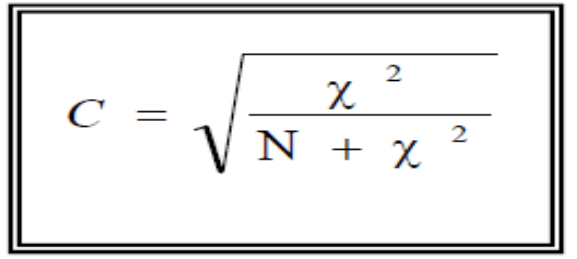

b. Nilai Chi-kuadrat (Chi-square):

$$
\chi^{2}=\sum_{i=1}^{r} \sum_{j-1}^{k} \frac{\left(O_{i j}-E_{i j}\right)^{2}}{E_{i j}}
$$

Hipotesis

$\mathrm{H} 0=0:$ Tidak ada hubungan antara variabel 1 dan variabel 2

$\mathrm{H} 1 \neq 0$ : Ada hubungan antara variabel 1 dan variabel 2

\section{Kriteria Keputusan}

Dengan nilai $\mathrm{a}=5 \%$ dan Derajat Bebas ( $\mathrm{y}$ ), $\mathrm{dk}$ $=(\mathrm{k}-1)(\mathrm{n}-1)$, maka

$\chi^{2}$ tabel $=(0.05,(\mathrm{k}-1)(\mathrm{n}-1))$

Dimana $: \mathrm{k}=$ jumlah baris dalam tabulasi.

$\mathrm{n}=$ jumlah kolom dalam tabulasi.

Maka

Tolak H0, jika nilai $\chi^{2}$ hitung $>\chi^{2}$ tabel

Terima H0, jika nilai $\chi^{2}$ hitung $<\chi^{2}$ tabel

\section{Penafsiran Korelasi}

Setelah melalui pengujian hipotesis dan hasilnya signifikan, (Hoditolak), maka untuk menentukan keeratan hubungan bisa digunakan kriteria berikut ini (Guilford, 1956). Interval Korelasi:

1. Tingkat hubungan yang sangat kecil dan bisa diabaikan: $<0,20$

2. Tingkat hubungan yang kecil (tidak erat): $0,20-0,40$

3. Tingkat hubungan yang cukup erat: $>0,40$

\section{Uji Validitas}

Uji validitas digunakan untuk sah atau valid tidaknya suatu kuesioner. Suatu kuesioner dikatakan valid jika pernyataan pada kuesioner mampu untuk mengungkapkan sesuatu yang akan diukur kuesioner tersebut. Uji signifikan dengan membandingkan nilai $r$ hitung dengan $r$ tabel untuk degree of freedom $(\mathrm{df})=\mathrm{n}-2$ dalam hal ini $\mathrm{n}$ adanlah jumlah sampel. Masing-masing item dikatakan valid apabila $r$ hitung $>r$ tabel. Pengujian validitas pada taraf yang signifikan digunakan adalah (a) $=5 \%$ atau 0,05 (Ghozali, 2006).

\section{Uji Reabilitas}

Uji reabilitas adalah alat untuk mengukur satu kuesioner yang merupakan indikator dari variabel atau kunstruk. Suatu kuesioner dikatakan relibel atau handal atau jawaban seseorang terhadap pertanyaan adalah konsisten atau stabil dari waktu ke waktu. Instrumen dinyatakn relibel apabila nilai alpha cronboach $>0,60$ (Ghozali, 2006).

\section{Instrumen Penelitian}

Penelitian ini menggunakan skala likert, Skala likert digunakan untuk mengukur sikap, pendapat, dan persepsi seorang atau sekelompok orang tentang fenomena sosial (Sugiyono, 2016). Jawaban setiap item instrumen yang menggunakan skala likert mempunyai gradiasi dari sangat setuju hingga sangat tidak setuju dengan diberikan skor untuk keperluan analisis kuantitatif Setuju $(\mathrm{S})=3$; Netral $(\mathrm{N})=2$; dan Tidak Setuju $(\mathrm{TS})=1$.

Penelitian ini merupakan penelitian kuantitatif, dengan menggunakan analisa deskriptif atau statistik deskriptif. Menurut Sugiono (2003:21) bahwa statistik deskriptif adalah statistik yang berfungsi untuk mendeskripsikan atau memberi gambaran terhadap objek yang diteliti melalui data sampel atau populasi sebagaimana adanya, tanpa melakukan analisis dan membuat kesimpulan yang berlaku untuk umum.

\section{HASIL DAN PEMBAHASAN}

\section{Sebaran Responden}

Penelitian yang dilakukan berdasarkan di 5 kampung pada Distrik Prafi. Adapun 5 kampung tersebut yaitu kampung Prafi Mulya, Desay, Sidomuncul Andagau, Aimasi dan Udapi Hilir. Data dibawah ini menunjukkan sebaran responden berdasarkan kampung.

Berdasarkan data diatas dapat dilihat bahwa jumlah responden terbanyak yaitu berada pada kampung Desay. Jumlah petani pada kampung Desay berjumlah 30 responden dengan nilai persentase yaitu sebesar 33 persen. Sedangkan 
jumlah responden terkecil yaitu berada pada kampung Aimasi. Jumlah petani pada kampung Aimasi berjumlah 11 responden dengan nilai persentase yaitu sebesar 12 persen.

Tabel 4. Responden Berdasarkan Kampung

\begin{tabular}{clcc}
\hline No & \multicolumn{1}{c}{ Kampung } & $\begin{array}{c}\text { Jumlah } \\
\text { Responden }\end{array}$ & $\begin{array}{c}\text { Persentase } \\
(\mathbf{\%})\end{array}$ \\
\hline 1 & Prafi Mulya & 27 & 30 \\
\hline 2 & Desay & 30 & 33 \\
\hline 3 & Sidomuncul Andagau & 8 & 9 \\
\hline 4 & Aimasi & 11 & 12 \\
\hline 5 & Udapi Hilir & 15 & 16 \\
\hline & Total & $\mathbf{9 1}$ & $\mathbf{1 0 0}$
\end{tabular}

\section{Sumber: Data Diolah (2019)}

Petani tidak memandang gender, artinya bahwa baik laki-laki maupun perempuan bisa menggeluti dunia pertanian. Responden dalam penelitian ini terdiri dari responden yang berbeda jenis kelamin laki-laki dan perempuan. Data dibawah ini menunjukan sebaran responden berdasarkan jenis kelamin.

Tabel 5. Responden Berdasarkan Jenis Kelamin

\begin{tabular}{clcc}
\hline No & Jenis Kelamin & $\begin{array}{c}\text { Jumlah } \\
\text { Responden }\end{array}$ & $\begin{array}{c}\text { Persentase } \\
(\mathbf{\%})\end{array}$ \\
\hline 1 & Laki-laki & 85 & 93 \\
\hline 2 & Perempuan & 6 & 7 \\
\hline & Total & $\mathbf{9 1}$ & $\mathbf{1 0 0}$ \\
\hline
\end{tabular}

Sumber: Data Diolah (2019)

Berdasarkan data diatas dapat dilihat bahwa jumlah responden yang lebih dominan yaitu responden berjenis kelamin laki-laki. Jumlah responden yang berjenis kelamin laki-laki yaitu sebesar 85 responden, dengan nilai persentase sebesar 93,4 persen. Sedangkan jumlah responden berjenis kelamin perempuan yaitu sebesar 6 responden, dengan nilai persentase sebesar 6,6 persen.

Tabel 6. Responden Berdasarkan Usia

\begin{tabular}{cccc}
\hline No & Usia (Tahun) & $\begin{array}{c}\text { Jumlah } \\
\text { Responden }\end{array}$ & $\begin{array}{c}\text { Persentase } \\
(\mathbf{\%})\end{array}$ \\
\hline 1 & $25-39$ & 32 & 35 \\
\hline 2 & $40-49$ & 40 & 44 \\
\hline 3 & $>50$ & 19 & 21 \\
\hline & Total & $\mathbf{9 1}$ & $\mathbf{1 0 0}$ \\
\hline
\end{tabular}

Sumber: Data Diolah (2019)

Usia kerja petani dalam penelitian ini dikelompokkan menjadi 3 kategori usia. Data dibawah ini menunjukan sebaran responden berdasarkan usia.

Berdasarkan data diatas dapat dilihat bahwa jumlah responden terbanyak yaitu responden yang berada dalam kelompok 40-49 tahun, dengan jumlah 40 responden. Nilai persentase untuk kelompok usia ini yaitu 44 persen. Sedangkan responden terkecil yaitu responden yang berada dalam kelompok $>50$ tahun, dengan jumlah 19 responden. Nilai persentase untuk kelompok usia ini yaitu 21 persen.

Tingkat pendidikan dalam penelitian ini dikelompokkan dalam latar belakang pendidikan setiap responden berbeda-beda. Data dibawah ini menunjukan sebaran responden berdasarkan tingkat pendidikan.

Tabel 7. Responden Berdasarkan Tingkat Pendidikan

\begin{tabular}{clcc}
\hline No & Tingkat Pendidikan & $\begin{array}{c}\text { Jumlah } \\
\text { Responden }\end{array}$ & $\begin{array}{c}\text { Persentase } \\
(\mathbf{\%})\end{array}$ \\
\hline 1 & Sekolah Dasar & 31 & 34 \\
\hline 2 & Sekolah Menengah Pertama & 34 & 37 \\
\hline 3 & Sekolah Menengah Atas & 26 & 29 \\
\hline \multicolumn{2}{c}{ Total } & $\mathbf{9 1}$ & $\mathbf{1 0 0}$ \\
\hline
\end{tabular}

Sumber: Data Diolah (2019)

Berdasarkan data diatas dapat dilihat bahwa jumlah responden terbanyak yaitu responden dengan tingkat pendidikan Sekolah Menengah Pertama (SMP). Responden dengan tingkat pendidikan SMP sebanyak 34 orang atau sebesar 37 persen. Sedangkan responden terkecil yaitu responden dengan tingkat pendidikan Sekolah Menengah Atas (SMA). Responden dengan tingkat pendidikan SMA sebanyak 26 orang atau sebesar 29 persen.

\section{Uji Validitas dan Uji Reliabilitas}

\section{Uji Validitas}

Pengujian validitas dilakukan dengan menggunakan Bivariate Correlation yang ditunjukkan pada taraf yang signifikan digunakan adalah (a) $=5 \%$ atau 0,05 maka data dikatakan valid, jika lebih kecil maka item tersebut dinyatakan tidak valid. Pengujian validitas menggunakan bantuan program SPSS 22. Uji signifikan dengan membandingkan nilai $r$ hitung dengan $r$ tabel untuk degree of freedom $(d f)=\mathrm{n}-2$ dalam hal ini $\mathrm{n}$ adalah jumlah sampel, jadi df yang digunakan adalah 91-2 = 89 dengan 
alpa sebesar 5\%, maka menghasilkan nilai $\mathrm{r}$ tabel sebesar 0.2061 sedangkan pada $r$ hitung untuk tiap hasilnya dapat dilihat pada kolom item-Total Correlation. Hasil pengujian validitas dapat dilihat pada tabel 5.5 dibawah ini.

Tabel 8. Hasil Uji Validitas

\begin{tabular}{|c|c|c|c|}
\hline Variabel & r Hitung & r Tabel & Keterangan \\
\hline \multicolumn{4}{|l|}{ Pendapatan } \\
\hline $\mathrm{X} 11$ & 0.223 & 0.2061 & Valid \\
\hline $\mathrm{X} 12$ & 0.355 & 0.2061 & Valid \\
\hline $\mathrm{X} 13$ & 0.309 & 0.2061 & Valid \\
\hline X14 & 0.361 & 0.2061 & Valid \\
\hline $\mathrm{X} 15$ & 0.404 & 0.2061 & Valid \\
\hline \multicolumn{4}{|c|}{$\begin{array}{c}\text { Kualitas dan } \\
\text { Kuantitas Hasil }\end{array}$} \\
\hline $\mathrm{X} 21$ & 0.656 & 0.2061 & Valid \\
\hline $\mathrm{X} 22$ & 0.565 & 0.2061 & Valid \\
\hline $\mathrm{X} 23$ & 0.492 & 0.2061 & Valid \\
\hline $\mathrm{X} 24$ & 0.375 & 0.2061 & Valid \\
\hline $\mathrm{X} 25$ & 0.647 & 0.2061 & Valid \\
\hline \multicolumn{4}{|l|}{$\begin{array}{l}\text { Perubahan } \\
\text { Teknologi }\end{array}$} \\
\hline $\mathrm{X} 31$ & 0.441 & 0.2061 & Valid \\
\hline X32 & 0.383 & 0.2061 & Valid \\
\hline X33 & 0.459 & 0.2061 & Valid \\
\hline X34 & 0.523 & 0.2061 & Valid \\
\hline X35 & 0.254 & 0.2061 & Valid \\
\hline \multicolumn{4}{|c|}{ Perubahan Iklim } \\
\hline Y11 & 0.713 & 0.2061 & Valid \\
\hline Y12 & 0.660 & 0.2061 & Valid \\
\hline Y13 & 0.434 & 0.2061 & Valid \\
\hline Y14 & 0.598 & 0.2061 & Valid \\
\hline Y15 & 0.468 & 0.2061 & Valid \\
\hline
\end{tabular}

Sumber: Data yang diolah (2019)

Tabel 8 menunjukan bahwa semua pernyataan dari setiap variabel Pendapatan (X1), Kualitas dan Kuantitas Hasil (X2), Perubahan Teknologi (X3), dan Perubahan Iklim (Y) mempunyai nilai korelasi yang positif dengan nilai $r$ hitung $>$ dari $\mathrm{r}$ tabel, sehingga keseluruhan butir dari setiap pernyataan yang ada dinyatakan valid.

\section{Uji Reliabilitas}

Uji reliabilitas ini diukur melalui koefisien alpa (Cronbach Alpha). Instrumen dikatakan reliabel adalah jika jawaban seseorang terhadap pernyataan adalah konsisten atau stabil dari waktu ke waktu. Instrumen dinyatakan reliabel apabila nilai cronbach alpha $>0,60$. Hasil uji reliabilitas dapat dilihat pada tabel dibawah ini.
Tabel 9. Hasil Uji Reliabilitas

\begin{tabular}{lcc}
\hline \multicolumn{1}{c}{ Variabel } & $\begin{array}{c}\text { Cronbach } \\
\text { Alpha }\end{array}$ & Keterangan \\
\hline Pendapatan (X1) & 0.707 & Reliabel \\
\hline Kuantitas dan Kualitas Hasil (X2) & 0.632 & Reliabel \\
\hline Perubahan Teknologi (X3) & 0.754 & Reliabel \\
\hline Perubahan Iklim (Y) & 0.810 & Reliabel \\
\hline Sumber: Data yang diolah (2019) & &
\end{tabular}

Sumber: Data yang diolah (2019)

Tabel 9 menunjukan bahwa semua instrumen penelitian yang digunakan untuk mengukur variabel Pendapatan (X1), Kualitas dan Kuantitas Hasil (X2), Perubahan Teknologi (X3), dan Perubahan Iklim (Y) adalah reliabel dan layak digunakan karena nilai koefisien cronbach alphanya lebih besar dari nilai batas kemungkinan reliabilitas yaitu 0,60 .

\section{Hasil Uji Crosstab dan Chi Square}

Dapat dilihat bahwa pendapatan pada kategori netral serta perubahan iklim pada kategori netral memiliki interval korelasi sebesar 12,5 persen. Pendapatan pada kategori setuju serta perubahan iklim memiliki interval korelasi sebesar 96,7 persen. Sehingga disimpulkan variabel ini memiliki hubungan yang cukup erat dengan perubahan iklim karena interval korelasinya lebih besar dari 0,40 persen.

Tabel 11. Perubahan Iklim Terhadap

Pendapatan

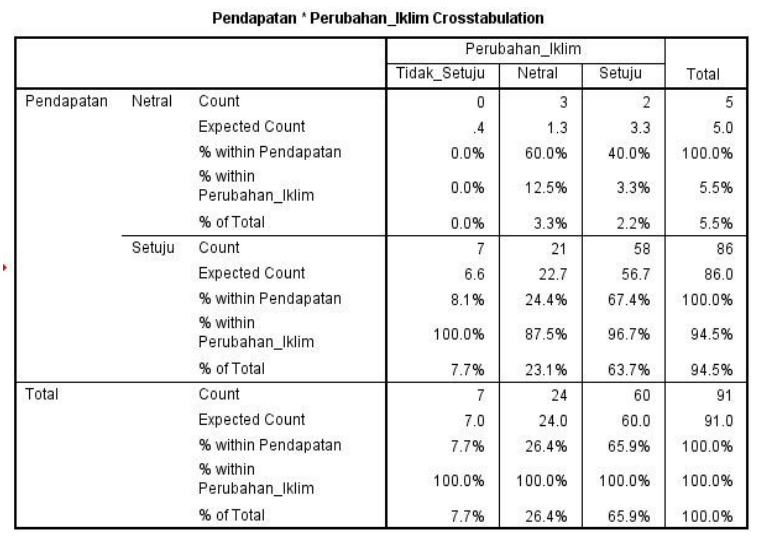

Sumber: Data yang diolah (2019)

Berdasarkan tabel diatas diketahui nilai chi square hitung adalah sebesar 3,215. Selanjutnya nilai chi square tabel untuk $\mathrm{df}=2$ pada signifikansi (a) 5\% atau 0,05 pada distribusi nilai chi square tabel statistik. Maka nilai chi square tabel sebesar 5,9915.

Berdasarkan pengambilan keputusan: 
1. Jika chi square hitung $<$ chi square tabel maka Ho diterima

2. Jika chi square hitung $>$ chi square tabel maka Ho ditolak

Karena nilai chi square hitung $3,215<$ chi square tabel 5,9915, maka dasar pengambilan keputusan diatas, dapat disimpulkan bahwa Ho diterima.

Berdasarkan probabilitas (signifikansi):

1. Jika probabilitas $>0,05$ maka Ho diterima

2. Jika probabilitas $<0,05$ maka Ho ditolak

Terlihat bahwa pada kolom Asymp.Sig adalah 0,200 , atau probabilitas diatas $0,05(0,200>0,05)$ maka Ho diterima. Dari kedua analisis di atas, bisa diambil kesimpulan yang sama, yaitu
Hoditerima, atau tidak ada hubungan antara pendapatan seseorang dengan perubahan iklim.

Tabel 12. Uji Chi-Square

\begin{tabular}{|c|c|c|c|}
\hline \multicolumn{4}{|c|}{ Chi-Square Tests } \\
\hline & Value & df & $\begin{array}{c}\text { Asymp. Sig. } \\
\text { (2-sided) }\end{array}$ \\
\hline Pearson Chi-Square & $3.215^{\mathrm{a}}$ & 2 & .200 \\
\hline Likelihood Ratio & 3.112 & 2 & .211 \\
\hline $\begin{array}{l}\text { Linear-by-Linear } \\
\text { Association }\end{array}$ & .439 & 1 & .508 \\
\hline$N$ of Valid Cases & 91 & & \\
\hline
\end{tabular}

Sumber: Data yang diolah (2019)

Tabel 13. Perubahan Iklim Terhadap Kulitas dan Kuantitas Hasil

\begin{tabular}{|c|c|c|c|c|c|}
\hline & & \multicolumn{3}{|c|}{ Perubahan_Iklim } & \multirow[b]{2}{*}{ Total } \\
\hline & & Tidak_Setuju & Netral & Setuju & \\
\hline \multirow{5}{*}{$\begin{array}{l}\text { Kualitas_dan_Kuantitas__ Setuju } \\
\text { Hasil }\end{array}$} & Count & 7 & 24 & 60 & 91 \\
\hline & Expected Count & 7.0 & 24.0 & 60.0 & 91.0 \\
\hline & $\begin{array}{l}\% \text { within } \\
\text { Kualitas_dan_Kuantitas__ } \\
\text { Hasil }\end{array}$ & $7.7 \%$ & $26.4 \%$ & $65.9 \%$ & $100.0 \%$ \\
\hline & $\begin{array}{l}\text { \% within } \\
\text { Perubahan_lklim }\end{array}$ & $100.0 \%$ & $100.0 \%$ & $100.0 \%$ & $100.0 \%$ \\
\hline & $\%$ of Total & $7.7 \%$ & $26.4 \%$ & $65.9 \%$ & $100.0 \%$ \\
\hline \multirow[t]{5}{*}{ Total } & Count & 7 & 24 & 60 & 91 \\
\hline & Expected Count & 7.0 & 24.0 & 60.0 & 91.0 \\
\hline & $\begin{array}{l}\% \text { within } \\
\text { Kualitas_dan_Kuantitas_ } \\
\text { Hasil }\end{array}$ & $7.7 \%$ & $26.4 \%$ & $65.9 \%$ & $100.0 \%$ \\
\hline & $\begin{array}{l}\text { \% within } \\
\text { Perubahan_Iklim }\end{array}$ & $100.0 \%$ & $100.0 \%$ & $100.0 \%$ & $100.0 \%$ \\
\hline & $\%$ of Total & $7.7 \%$ & $26.4 \%$ & $65.9 \%$ & $100.0 \%$ \\
\hline
\end{tabular}

Sumber: Data yang diolah (2019)

Dapat dilihat bahwa kualitas dan kuantitas hasil pada kategori setuju serta perubahan iklim pada kategori setuju memiliki interval korelasi sebesar 65,9 persen. Sehingga disimpulkan variabel ini memiliki hubungan yang cukup erat dengan perubahan iklim karena interval korelasinya lebih besar dari 0,40 persen.

Tabel 14. Uji Chi-Square

\begin{tabular}{|c|c|c|c|}
\hline \multicolumn{4}{|c|}{ Chi-Square Tests } \\
\hline & Value & df & $\begin{array}{l}\text { Asymp. Sig. } \\
\text { (2-sided) }\end{array}$ \\
\hline Pearson Chi-Square & $3.217^{\mathrm{a}}$ & 2 & .203 \\
\hline Likelihood Ratio & 3.119 & 2 & .219 \\
\hline $\begin{array}{l}\text { Linear-by-Linear } \\
\text { Association }\end{array}$ & .435 & 1 & .507 \\
\hline $\mathrm{N}$ of Valid Cases & 91 & & \\
\hline
\end{tabular}

a. 3 cells $(50.0 \%)$ have expected count less than 5 . The minimum expected count is 38 .

Sumber: Data yang diolah (2019)
Berdasarkan tabel 14 diketahui nilai chi-square hitung adalah sebesar 3,217. Selanjutnya nilai chi square tabel untuk $\mathrm{df}=2$ pada signifikansi (a) $5 \%$ atau 0,05 pada distribusi nilai chi square tabel statistik. Maka nilai chi square tabel sebesar 5,9915.

Berdasarkan pengambilan keputusan:

1. Jika chi square hitung < chi square tabel maka Ho diterima

2. Jika chi square hitung $>$ chi square tabel maka Ho ditolak

Karena nilai chi square hitung $3,217<$ chi square tabel 5,9915, maka dasar pengambilan keputusan diatas, dapat disimpulkan bahwa Ho diterima.

Berdasarkan probabilitas (signifikansi):

1. Jika probabilitas $>0,05$ maka Ho diterima 


\section{Jika probabilitas $<0,05$ maka Ho ditolak}

Terlihat bahwa pada kolom Asymp.Sig adalah 0,203 , atau probabilitas diatas $0,05(0,203>0,05)$ maka Ho diterima. Dari kedua analisis di atas, bisa diambil kesimpulan yang sama, yaitu Hoditerima, atau tidak ada hubungan antara kualitas dan kuantitas hasil dengan perubahan iklim.

Dapat dilihat bahwa perubahan teknologi pada kategori setuju serta perubahan iklim pada kategori setuju memiliki interval korelasi sebesar 65,9 persen. Sehingga disimpulkan variabel ini memiliki hubungan yang cukup erat dengan perubahan iklim karena interval korelasinya lebih besar dari 0,40 persen.

Tabel 15. Uji Chi-Square

Chi-Square Tests
\begin{tabular}{|l|r|r|r|}
\hline \multicolumn{1}{|c|}{} & \multicolumn{1}{c|}{ Value } & df & $\begin{array}{c}\text { Asymp. Sig. } \\
(2 \text {-sided })\end{array}$ \\
\hline Pearson Chi-Square & $3.212^{\text {a }}$ & 2 & .230 \\
Likelihood Ratio & 3.129 & 2 & .221 \\
Linear-by-Linear & .432 & 1 & .517 \\
Association & 91 & & \\
N of Valid Cases & \\
a. 3 cells (50.0\%) have expected count less than 5. The minimum \\
expected count is .38.
\end{tabular}

\section{Sumber: Data yang diolah (2019)}

Berdasarkan tabel diatas diketahui nilai chi square hitung adalah sebesar 3,212. Selanjutnya nilai chi square tabel untuk $\mathrm{df}=2$ pada signifikansi (a) 5\% atau 0,05 pada distribusi nilai chi square tabel statistik. Maka nilai chi square tabel sebesar 5,9915.

Berdasarkan pengambilan keputusan:

1. Jika chi square hitung $<$ chi square tabel maka Ho diterima

2. Jika chi square hitung $>$ chi square tabel maka Ho ditolak

Karena nilai chi square hitung $3,212<$ chi square tabel 5,9915, maka dasar pengambilan keputusan diatas, dapat disimpulkan bahwa Ho diterima.

Berdasarkan probabilitas (signifikansi):

1. Jika probabilitas $>0,05$ maka Ho diterima

2. Jika probabilitas $<0,05$ maka Ho ditolak

Terlihat bahwa pada kolom Asymp.Sig adalah 0,230 , atau probabilitas diatas $0,05(0,230>0,05)$ maka Ho diterima. Dari kedua analisis di atas, bisa diambil kesimpulan yang sama, yaitu Hoditerima, atau tidak ada hubungan antara perubahan teknologi yang digunakan dengan perubahan iklim.

\section{KESIMPULAN}

Berdasarkan kuesioner yang telah dibagikan kepada responden, dan rumusan masalah dapat dilihat bahwa tidak terdapat hubungan antara perubahan iklim dengan kualitas dan kuantitas hasil serta perubahan teknologi secara bersamasama. Hal ini dikarenakan hasil nilai interval korelasi dan nilai chi square lebih besar dari taraf signifikansi sehingga tidak ada korelasi.

Selanjutnya, tidak terdapat hubungan antara kualitas dan kuantitas hasil dengan pendapatan. Dan tidak terdapat hubungan antara perubahan teknologi dengan pendapatan. Hal ini dikarenakan petani padi sudah menggunakan teknologi modern sebelum adanya isu tentang pengaruh perubahan iklim serta dengan adanya perubahan teknologi tersebut memberikan kualitas dan kuantitas padi yang baik sehingga pendapatan petani tetap meningkat dan tidak terganggu dengan perubahan iklim yang akan terjadi.

\section{SARAN}

Bagi pemerintah, untuk lebih meningkatkan anggaran di bidang pertanian agar lebih menunjang proses pertanian yang bertujuan untukmeningkatkan hasil produksi di sektor pertanian khususnya padi. Bagi masyarakat, diharapkan untuk terus memberikan inovasiinovasi terbaru sehingga petani padi mulai menggunakan perubahan teknologi dalam menyikapi perubahan iklim yang terjadi. Bagi peneliti selanjutnya. Diharapkan untuk menambah variabel-variabel lain untuk memperluas cakupan penelitian dan untuk mengetahui apakah ada hubungan dengan perubahan iklim yang terjadi.

\section{UCAPAN TERIMAKASIH}

Terimakasih kami sampaikan kepada saudara Dinda P.Putri Gadi yang telah bersedia menjadi enumerator dalam penelian ini, serta memberikan datanya untuk kami analisis.

\section{DAFTAR PUSTAKA}

Aliadi, Arif, dkk. 2008. Perubahan Iklim Hutan dan REED: Peluang atau Tantangan Kemitraan Bogor. 
Badan Pusat Statistik (BPS), Kabupaten Manokwari, "Jumlah Curah Hujan, LuasPanen, Produktivitas, dan Produksi di Tahun 2013-2017". Manokwari Dalam Angka

Handoko Y, Sugiarto, Syaukat Y., 2008, Keterkaitan Perubahan Iklim dan Produksi Pangan Stategis: Telaah Kebijakan Independen dalam Bidang Perdagangan dan Pembangunan, Bogor: Seameo Biotrop

Iskandar, Alisjahbana, 1980.Teknologi dan Perkembangan, Yayasan Idayu, Jakarta,

Mubyarto. 1994.Pengantar Ekonomi Pertanian. LP3ES: Jakarta

Nana Syaodih. 2007. Metode Penelitian Pendidikan. Bandung: Rosdakarya.
Soekartawi.2002.Analisis Usahatani.Jakarta: Universitas Indonesia

Suberjo, 2009. Adaptasi Pertanian dalam Pemanasan Global. Dosen Fakultas Pertanian UGM Yogyakarta dan Mahasiswa Doktoral The University of Tokyo. http://subejo.staff.ugm.ac.id/?p=108.Dia kses pada 01 Oktober 2019 jam. 23.10 WIT.

Sugiyono, 2009, Metode Penelitian Kuantitatif, Kualitatif dan R\&D, Bandung : Alfabeta

Wungu, Jiwo dan Brotoharsojo, Hartanto. 2003. Tingkatkan Kinerja Perusahaan dengan Merit System, Jakarta: Raja Grafindo Persada 